\title{
Work related symptoms among sewage workers
}

\author{
MONICA LUNDHOLM'1 AND R RYLANDER ${ }^{2}$ \\ From the Department for Clinical Bacteriology, ${ }^{1}$ Academy Hospital, Uppsala, and the Department of \\ Environmental Hygiene, ${ }^{2}$ University of Gothenburg, Gothenburg, Sweden
}

\begin{abstract}
Employees at six sewage treatment plants and three drinking water plants were interviewed for the presence of specific medical symptoms. Serum immunoglobulin concentrations, white blood cell counts and fibrinogen degradation product concentrations (FDP) in urine were determined as were the number and species of airborne Gram negative rods in order to characterise exposure to aerosols of sewage water. The highest number of bacteria was found in areas where the sewage water was agitated. A significantly higher proportion of employees at sewage treatment plants reported skin disorders, diarrhoea, and other gastrointestinal symptoms than the control group. No significant differences were found between the groups for white blood cell count or serum immunoglobulin concentrations, except that IgM concentrations were slightly higher in the sewage workers. Some workers had serum transaminase concentrations in excess of normal; some of these returned to normal after the summer holiday. Among non-smokers a higher proportion of sewage treatment workers had increased amounts of FDP in urine. It is conceivable that the symptoms observed were caused by toxins from Gram negative bacteria.
\end{abstract}

The occupational health risks of sewage workers have been investigated by several authors, and reviews have been presented by Anders ${ }^{1}$ and Clark. ${ }^{2}$ The emphasis in most investigations has been on the risk of contracting various types of infectious diseases.

A previous study on sewage workers reported that when sewage sludge was heat-dried, employees experienced attacks of fever, chills, and eye inflammation after exposure to high concentrations of the dust. ${ }^{3}$ The concentrations of serum immunoglobulins and fibrogen degradation products (FDP) in urine were increased in exposed workers. The symptoms were interpreted as being caused by the endotoxin in the dust, originating from Gram negative bacteria in the sewage sludge.

This present paper reports a study undertaken to determine whether specific symptoms were also present among sewage workers in plants where sludge was treated by conventional methods. Workers in drinking water plants served as a reference population. The presence of medical symptoms was studied in interviews and serum immunoglobulin concentrations, white blood cell counts, and FDP concentrations in the urine were measured. The exposure to sewage water aerosols was characterised by measur-

Received 15 February 1982

Accepted 26 August 1982 ing the number of airborne Gram negative rods. A preliminary report of this work has been presented elsewhere. 4

\section{Materials and methods}

PLANTS INVESTIGATED

The investigation was performed at six different sewage water treatment plants in Sweden (three indoors and three outdoors) and three drinking water plants.

All sewage treatment plants were equipped for high degree (biological) treatment of the sewage water, and usually also for chemical treatment. None received industrial water containing particularly toxic substances.

\section{BACTERIA SAMPLING}

The number of airborne Gram negative rods was determined with a six stage Andersen sampler, ${ }^{5}$ using Drigalski agar (see appendix) as a selective medium. After incubation at $30^{\circ}$ for $40-65$ hours, the number of colonies was counted and corrected as recommended by Andersen ${ }^{5}$ and May. ${ }^{6}$ The results were reported as the mean number of colony forming units (cfu) per cubic meter of air. Several samples were taken at breathing level at the different working sites and the measurements were repeated on two or more occasions on different days. 
Colonies on plates from different parts of the sewage plants were selected for species determination. Three to six isolates of colonies with different morphology, which appeared in more than about $5 \%$ of the total count of bacteria on the investigated plates, were subcultured. Species determinations were done with conventional bacteriological techniques, including the API microtube $20 \mathrm{E}$ profile system (Analytab Products, Plainview, NY). Nonfermentative strains were further analysed according to Cowan and Steel ${ }^{7}$ and Gilardi. ${ }^{8}$ Specific determinations of airborne fungi were not made. The size of the particles carrying viable bacteria was estimated by the distribution of bacterial colonies on the different stages of the Andersen sampler.

\section{MEDICAL EFFECTS}

All employees working in the plants at the time of the investigation and who had been employed for at least eight months were interviewed. Of the 250 workers identified using these criteria, only two refused to participate. Eight could not be contacted due to long time absence from work.

Forty one employees at the drinking water plants and 199 at the sewage treatment plants were investigated. Most of those investigated were men. There were no statistically significant differences between workers in sewage and drinking water plants concerning mean age $(41 v 47)$ or the proportion of current smokers ( $44 v 56 \%$ ). The mean employment time was shorter in sewage plants than in drinking water plants ( $7 v 13$ years, NS).

The questionnaire contained questions on smoking habits, work related symptoms such as eye inflammation, attacks of fever, gastrointestinal symptoms, skin disorders, and pulmonary symptoms. All interviews were performed either by us or occasionally by the occupational health physician at the plant.

Blood was taken to determine the number of white blood cells and their distribution, the number of platelets, and the amount of serum immunoglobulins. Urine was taken to determine the concentration of fibrinogenic degradation products as an indicator of inflammation.

A separate investigation was later undertaken to measure serum transaminase (ASAT and ALAT) concentrations. This study was made in two plants, one of which was included for the main study. For practical reasons it was not feasible to do these determinations in all plants. Transaminase determinations were made on serum taken before and after a working operation that exposed the employees to particularly high concentrations of sewage aerosols and before and after the summer vacation.

Differences between various groups were tested for statistical significance using the Student's $t$ test (two tailed) or the Wilcoxon matched pair test.

\section{Results}

\section{BACTERIAL EXPOSURE}

The results from the determinations of airborne Gram negative rods in sewage treatment plants showed that the number of $\mathrm{cfu} / \mathrm{m}^{3}$ varied from 10 to more than $10^{5} / \mathrm{m}^{3}$. High numbers were found at areas where the water was agitated or where sprinkling water systems were used $\left(>10^{5} / \mathrm{m}^{3}\right)$. In drinking water plants the number was about $10 \mathrm{cfu} / \mathrm{m}^{3}$ of air.

Regarding different species of Gram negative bacteria, Klebsiella pneumoniae was found in all plants (5-20\% of the total number of Gram negative rods). The proportion of Escherichia coli varied from a few per cent to $20 \%$; in several measurements no $E$ coli could be found. Enterobacter agglomerans and Aeromonas hydrophila were often present in high numbers, as was Acinetobacter calcoaceticus. Pseudomonas strains (syringae, maltophilia, fluorescens, putida, and diminuta) constituted up to $10 \%$ of the Gram negative rods. Agrobacterium, Flavobacterium, and Serratia spp as well as Citrobacter freundii were found in low numbers in some plants. Most of the bacteria carrying particles were of sizes equal to or larger than $5 \mu \mathrm{m}(62 \%) ; 40 \%$ of the particles were $8.2 \mu \mathrm{m}$ or larger.

\section{EXAMINATION OF EMPLOYEES}

Table 1 shows the answers to questions concerning different work related symptoms. Among the employees at the drinking water plants, work related symptoms were reported by a small proportion of the employed. "Tiredness" due to work was reported by a higher proportion of smokers than non-smokers, but the difference was not statistically significant.

At the sewage treatment plants, the proportion of

Table 1 Subjective work related symptoms among employees in drinking water plants and sewage treatment plants

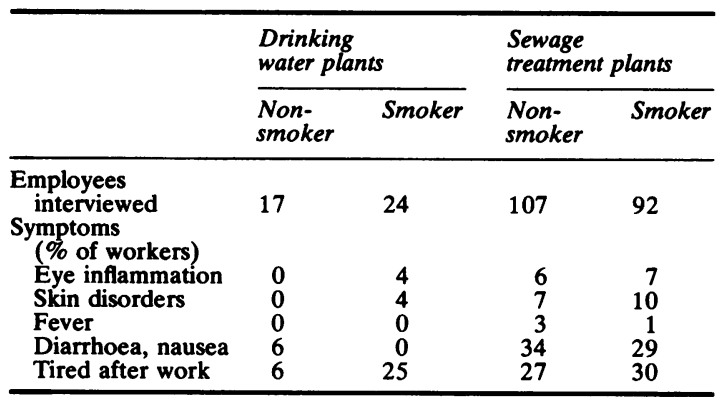


Table 2 Work related gastrointestinal symptoms and airborne content of Gram negative rods (cfu/1). Employees were divided according to their main working sites. Workers with low exposure may occasionally also work in highly exposed areas

\begin{tabular}{|c|c|c|}
\hline Exposure & High & Low \\
\hline \multirow{2}{*}{$\begin{array}{l}\text { cfu/1 } \\
\text { No (\%) of workers with } \\
\text { gastrointestinal symptoms }\end{array}$} & $20-50$ & $0.2-3 \cdot 5$ \\
\hline & $67(37)$ & $53(21)$ \\
\hline
\end{tabular}

workers who reported symptoms was approximately equal among smokers and non-smokers. Among non-smokers, a significantly higher proportion reported skin disorders $(p<0 \cdot 01)$, diarrhoea, and other gastrointestinal symptoms $(p<0.001)$ than in drinking water plants.

Table 2 shows the percentage of workers reporting gastrointestinal symptoms in relation to the number of airborne Gram negative rods at high and low exposed working sites. Aerated basins with sprinkler systems, incoming water tunnels, and sludge treatment areas were considered as areas of high exposure. The bacterial counts at these sites were from 20 to more than $50 \mathrm{cfu} / 1$ air. Sites of low exposure were sedimentation basins and other parts of the plant, where the water was not agitated $(0 \cdot 2-$ $3.5 \mathrm{cfu} / 1$ ). In two plants it was not possible to differentiate between workers with high and low exposure.

Employees mainly working in highly exposed sites reported symptoms to a greater extent (37\%) than those working in sites with low exposure $(21 \%$, $\mathrm{p}<0.05$ ).

The occurrence of gastrointestinal symptoms was often reported to be related to a particular job, such as cleaning basins and servicing pumps. The symptoms began a few hours after the work had started and disappeared by the following morning. Usually these symptoms were reported to occur infrequently but particularly after the return from the annual holiday. Among certain employees, however, they were present several times a month or even more often.

\section{CLINICAL TESTS}

No differences were found in the number of white blood cells or their distribution, or the number of platelets between the employees at the sewage treatment plants and those at the drinking water plants. Nevertheless, the number of white blood cells in smokers was significantly higher, both in the workers in the sewage treatment plants and in the drinking water plants (table 3 ). Smokers in the sewage treatment plants had a significantly lower number of white blood cells than smokers in the drinking water plants $(p<0 \cdot 005)$.

Concerning the serum immunoglobulin concen-
Table 3 Mean white blood cell count in smoking and non-smoking workers at sewage treatment and drinking water plants. Standard deviation in parentheses.

\begin{tabular}{ll}
\hline Exposure & $\begin{array}{l}\text { White } \\
\text { blood cells }\left(10^{\circ} l\right)\end{array}$ \\
\hline Sewage plant: & \\
$\quad$ Non-smokers $(\mathrm{n}=95)$ & $5.5(1.4)$ \\
Smokers $(\mathrm{n}=86)$ & $7.2(2 \cdot 1)^{*}$ \\
Drinking water: & $5.6(1.2)$ \\
$\quad$ Non-smokers $(\mathrm{n}=17)$ & $8.9(2.7)^{* *}$ \\
Smokers $(\mathrm{n}=24)$ & \\
\hline$=\mathrm{p}<0.005$. & \\
$* *=\mathrm{p}<0.001$. &
\end{tabular}

trations, no differences could be found between smokers and non-smokers in the two types of plants. The concentrations of IgG and IgM were higher in the employees at the sewage treatment plants, but the differences were statistically significant only for $\operatorname{IgM}(1.3 v 1.7 \mathrm{~g} / \mathrm{l}, \mathrm{p}<0.005)$.

Table 4 illustrates the proportion of employees with urinary FDP levels in excess of $10 \mathrm{mg} / \mathrm{l}$. Among the employees at drinking water plants, a higher proportion of smokers had increased FDP levels, though the difference was not statistically significant. When non-smokers in the two groups were compared, a significantly higher proportion of employees at sewage treatment plants was found to have increased amounts of FDP in urine $(p<0.001)$.

The mean serum transaminase values of workers in the sewage plants before and after highly exposed work, and before and after the annual vacation were about the same. Of 16 individuals tested, six had ASAT values in excess of the normal upper limit of $0.70 \mu \mathrm{kat} / 1$ when investigated before the vacation. In five of these the values after vacation were lower, in four below $0.70 \mu \mathrm{kat} / \mathrm{l}$.

\section{Discussion}

A comparison of three different methods used for the determination of airborne bacteria9 ${ }^{9}$ shows that the Andersen sampler used in this study yields the highest number of cfu when airborne Gram negative rods are determined.

Table 4 Percentage of employees with urinary fibrinogen degradation product concentrations in excess of $10 \mathrm{mg} / \mathrm{l}$

\begin{tabular}{|c|c|c|c|c|}
\hline & \multicolumn{2}{|c|}{$\begin{array}{l}\text { Drinking } \\
\text { water plants }\end{array}$} & \multicolumn{2}{|c|}{$\begin{array}{l}\text { Sewage } \\
\text { treatment plants }\end{array}$} \\
\hline & $\begin{array}{l}\text { Non- } \\
\text { smoker }\end{array}$ & Smoker & $\begin{array}{l}\text { Non- } \\
\text { smoker }\end{array}$ & Smoker \\
\hline $\begin{array}{l}\text { No of employees } \\
\text { investigated } \\
\text { Increased FDP \% }\end{array}$ & $\begin{array}{r}18 \\
6\end{array}$ & $\begin{array}{l}23 \\
22\end{array}$ & $\begin{array}{l}89 \\
33^{*}\end{array}$ & $\begin{array}{l}79 \\
24\end{array}$ \\
\hline
\end{tabular}

* $p<0.001$ (in relation to non-smoking workers at drinking water plants.) 
Owing to the aggregation of several bacteria into single airborne particles, the cfu value obtained with the impinger technique on to agar underestimates the true number of airborne viable cells. In the sewage plant environment the true number has been shown to be about 25 times higher than the number of cfu recorded with the Andersen sampler. ${ }^{9}$ This must be kept in mind when dose levels for specific compounds, such as toxins found in bacteria, are evaluated.

The highest number of viable Gram negative rods was found close to working processes where the sewage water was agitated. The specific sites at which a high number of bacteria were found differed among the plants. In certain plants a high number of bacteria was found near aerated basins or in inlet tunnels, in others the number of bacteria at these sites was low.

The major source of the bacteria found in sewage water is the natural environment. Klebsiella, Enterobacter, Aeromonas, and non-fermentative Gram negative rods dominated the aerobic flora. These strains are commonly found in samples of water, soil, and vegetation ${ }^{10}{ }^{11}$ and also in faecal flora of wild birds. ${ }^{12}$ Bacteria from human faeces, such as $E$ coli, were generally present in low numbers. This is in accordance with the findings of other authors. ${ }^{13}$

The presence of subjective symptoms in the groups of employees was assessed with the aid of interviews and since the participation rate was high, no bias occurred due to the drop out group.

A significantly higher proportion of sewage workers reported work related gastrointestinal symptoms, such as diarrhoea. The extent of symptoms was related to a crude exposure differentiation using high and low exposure sites. Similar symptoms have been reported from other work environments, such as composting plants, where high numbers of airborne Gram negative bacteria were present. ${ }^{14}$ The symptoms reported were acute with respect to the exposure, with an incubation period of one or more hours, and disappeared rapidly. It is not likely, therefore, that they are caused by an infection especially as white blood cell counts were normal.

A tendency to a higher frequency of eye inflammation and tiredness after work was also found; similar symptoms have also been reported in studies of sewage treatment workers in Denmark ${ }^{15}$ and in Canada. ${ }^{16}$

Why the symptoms developed in the sewage workers is not clear. The air in the sewage treatment plants is contaminated with aerosols from the sewage water containing bacteria, viruses, fungi, worm eggs, and chemical compounds and thus it is difficult to determine which might have caused the symptoms.
There are no reasons to believe that chemical compounds in the sewage water are the cause of the symptoms reported in this investigation as similar symptoms were found in a plant composting household garbage where no chemicals were present. ${ }^{14}$ It is well known that some strains of Gram positive bacteria produce toxins that cause gastrointestinal symptoms. The number of such bacteria however, was relatively low, and the inhaled dose is unlikely to be large enough to cause symptoms.

Gastrointestinal symptoms such as those seen among the workers in the sewage plants have been reported in connection with exposure to Gram negative bacteria. Waslien et al showed that people who ingested washed and lyophilised cells of Aerobacter aerogenes developed gastrointestinal symptoms and diarrhoea a few hours later. ${ }^{17}$ Similar symptoms have been reported in connection with exposure to enterotoxins, which are produced by a number of Gram negative rods such as Klebsiella, Citrobacter, Enterobacter, Aeromonas, Proteus, and Pseudomonas. ${ }^{18} 19$ Strains from species such as $E$ agglomerans, $K$ pneumoniae, and $P$ fuorescens, $P$ maltophilia, and $P$ putida isolated from food samples were also shown to give a positive rabbit ileal loop test. ${ }^{19}$ This indicates that they can cause diarrhoea in man. Enterotoxin producing $E$ coli and Klebsiella have also been suspected of producing epidemic diarrhoea. ${ }^{20}$

Annapurna and Sanyal found that live cells at a concentration of $10^{3}-10^{4}$ cells $/ \mathrm{ml}$ and cell free culture supernatants of $\mathbf{5 0}$ strains of $\boldsymbol{A}$ hydrophila isolated from man, drinking water, domestic animals, and sewage, caused accumulation of fluid in rabbit ileal loop tests. ${ }^{21}$ This reaction does not require colonisation of the human intestine.

In view of these observations, it seems likely that the aetiological agents for the symptoms are enterotoxins from the Gram negative bacteria present in high numbers in the sewage environment. The content of enterotoxin in the sewage water remains to be determined.

Gram negative bacteria also carry endotoxin in their outer cell envelope. Endotoxin that reaches the intestine is partly resorbed by the intestinal wall and transported to the liver, where it is detoxified. ${ }^{22}$ The increased burden of endotoxin could explain the increases in serum transaminases found in certain workers in this and other studies. ${ }^{23} 24$ As endotoxins act as mitogens, this exposure could also explain the increase in IgM concentrations found in the sewage plant workers. Increased exposure to bacterial toxins may also have caused the increases in urinary FDP values found in the sewage workers.

There are no reasons to believe, however, that endotoxins are responsible for gastrointestinal 
symptoms in the sewage workers. Endotoxin has been tested in ligated pig intestine, but was shown to have no effect similar to that of enterotoxins. ${ }^{25}$

Apart from work related symptoms, differences were also found between non-smokers and smokers. An increased number of white cells in smokers has been reported by several authors but the increase in FDP concentrations has not. The reasons for this increase are not known, but a plausible mechanism is that the subchronic irritation of the lung epithelium, with effects on pulmonary macrophages and polymorphonuclear leukocytes results in faster cell turnover and excess cell death.

In conclusion, the data from this study suggest that workers in sewage treatment plants have specific, work related symptoms that are due to acute effects of toxins from Gram negative bacteria in the environment. To avoid the occurrence of symptoms among exposed workers, determinations of airborne Gram negative bacteria should be made in sewage treatment plants and technical measures undertaken to reduce the number at sites where it is high.

This work was supported by grant $76 / 9$ from the Swedish Work Environment Fund.

\section{Appendix}

\section{DRIGALSKI AGAR}

101 solution:

$100 \mathrm{~g}$ Meat extract Lab-Lemco oxoid L 29

$100 \mathrm{~g}$ Peptone oxoid L 34

$50 \mathrm{~g} \mathrm{NaC1}$

$140 \mathrm{~g}$ Portuguese agar or commercial agar

$10 \mathrm{~g}$ Natriumthiosulphate $\mathrm{Na}_{2} \mathrm{~S}_{2} \mathrm{O}_{3} \cdot 5 \mathrm{H}_{2} \mathrm{O}$

$400 \mathrm{ml}$ Bromthymol blue $0.2 \%$

$50 \mathrm{ml}$ Crystal violet solution $0 \cdot 1 \%$

$100 \mathrm{~g}$ Lactose

Dilute in dest water to 10 litres

\section{References}

${ }^{1}$ Anders W. Die Berliner Kanal Betriebsarbeiter. Zeitschrift für Hygiene 1954;139:341-71.

${ }^{2}$ Clark SC. Disease risks of occupational exposure to sewage. Journal of the Environmental Engineering Division, Proceedings of the American Society of Civil Engineers 1976;102:375-88.

${ }^{3}$ Rylander R, Andersson K, Belin L, et al. Studies on humans exposed to airborne sewage sludge. Schweiz Med Wochenschr 1977;107:182-4.

4 Rylander R, Lundholm M. Responses to wastewater exposure with reference to endotoxin. In: Pahren $\mathrm{H}$, Jakubowski W, eds. Wastewater aerosols and disease. Proceedings of a symposium 19-21 September 1979. Cincinnati, Ohio: US Environmental Protection Agency, 1980: 90-8. (EPA-600/ 9-80-028.)
${ }^{5}$ Andersen AA. New sampler for the collection, sizing and enumeration of viable airborne particles. J Bacteriol 1958;76:47184.

- May KR. Calibration of a modified Andersen bacterial aerosol sampler. Applied Microbiology 1964;12:37-43.

${ }^{7}$ Cowan ST, Steel KJ. Manual for the identification of medical bacteria. Cambridge: Cambridge University Press, 1974.

- Gilardi GL, ed. Glucose. In: Nonfermenting Gram negative bacteria in clinical microbiology. Cleveland, Ohio: CRC Press Inc, 1978.

${ }^{9}$ Lundholm M. Comparison of methods for quantitative determinations of airborne bacteria and evaluation of total viable counts. Appl Environ Microbiol 1982;44:179-83.

${ }^{10}$ Duncan DW, Razell WE. Klebsiella biotypes among coliforms isolated from forest environments and farm products. Applied Microbiology 1972;24:933-8.

" Rylander R, Lundholm M. The bacterial contamination of cotton and cotton dust and effects on the lung. $B r J$ Ind Med 1978;35:204-7.

${ }^{12}$ Damaré JM, Hussong D, Weiner RM, Colwell RR. Aerobic and facultatively anaerobic bacteria associated with the gut of Canada geese (Branta canadensis) and whistling swans (Cygnus columbianus columbianus). Appl Environ Microbiol 1979;38:258-66.

13 Johnson DE, Camann DE, Register JW, et al. Health effects from wastewater aerosols at a new activated sludge plant: John Egan Plant, Schawnberg, Illinois. In: Pahren H, Jakubowski $\mathrm{W}$, eds. Wastewater aerosols and disease. Proceedings of a symposium, 19-21 September Cincinnati, Ohio: US Environmental Protection Agency, 1980: 136-59. (EPA-600/9-80028.)

${ }^{14}$ Lundholm M, Rylander R. Occupational symptoms among compost workers. JOM 1980;22:256-7.

15 Andersen JM, Egsmose L, Egsmose T. Kloakarbejderrapporten. Copenhagen: FADL förlag, 1976. (In Danish.)

${ }^{16}$ Sekla L, Gemmill D, Manfreda J, et al. Sewage treatment plant workers and their environment: A health study. In: Pahren $\mathbf{H}$, Jakubowski W, eds. Wastewater aerosols and disease. Proceedings of a symposium. 19-21 September 1979. Cincinnati, Ohio: US Environmental Protection Agency 1980; 281-94. (EPA-600/9-80-028.)

17 Waslien CI, Calloway DH, Margen S. Human intolerance to bacteria as food. Nature 1969;221:84-5.

18 Wadström T, Aust-Kettis A, Habte D, et al. Enterotoxinproducing bacteria and parasites in stools of Ethiopian children with diarrhoeal disease. Arch Dis Child 1976;51:865-70. 1976;51:865-70.

19 Jiwa SFH, Krovacek K, Wadström T. Enterotoxigenic bacteria in food and water from an Ethiopian community. Appl Environ Microbiol 1981;41:1010-9.

${ }^{20}$ Danielsson M-L, Möllby R, Brag $\mathrm{H}$, et al. Enterotoxigenic enteric bacteria in foods and outbreaks of food-borne diseases in Sweden. J Hyg (Camb) 1979;83:33-40.

${ }^{21}$ Annapurna E, Sanyal SC. Enterotoxicity of Aeromonas hydrophila. J Med Microbiol 1977;10:317-23.

${ }^{22}$ Utili R, Abernathy CO, Zimmerman HJ. Endotoxin effects on liver. Life Sciences 1977;20:553-68.

${ }^{23}$ Hogstedt C, Ohlson C-G. Liver function among workers in sewage plants. Läkartidningen 1980;77:614-5. (In Swedish.)

${ }^{24}$ Clark CS, Van Meer GL, Linnemann CC Jr, et al. Health effects of occupational exposure to wastewater. In: Pahren $\mathbf{H}$, Jakubowski W, eds. Wastewater aerosols and disease. Proceedings of a symposium 19-21 September 1979. Cincinnati, Ohio: US Environmental Protection Agency, 1980; 239-64. (EPA600/9-80-028.)

${ }^{25}$ Smith HW, Halls S. Studies on Escherichia coli enterotoxin. Journal of Pathology and Bacteriology 1967;93:531-43. 